\title{
Effect of Temperature on Sporulation and Infectivity of Podosphaera macularis on Humulus lupulus
}

\author{
Amy B. Peetz, Oregon State University, Department of Botany and Plant Pathology, Corvallis, OR 97331; Walter F. \\ Mahaffee, U.S. Department of Agriculture-Agricultural Research Service, Horticultural Crops Research Laboratory, \\ and Oregon State University, Department of Botany and Plant Pathology, Corvallis, OR 97331; David H. Gent, U.S. \\ Department of Agriculture-Agricultural Research Service, Forage Seed and Cereal Research Unit, and Oregon State \\ University, Department of Botany and Plant Pathology, Corvallis, OR 97331
}

\begin{abstract}
Peetz, A. B., Mahaffee, W. F., and Gent, D. H. 2009. Effect of temperature on sporulation and infectivity of Podosphaera macularis on Humulus lupulus. Plant Dis. 93:281-286.

Hop powdery mildew, caused by Podosphaera macularis, can result in complete crop loss and requires numerous fungicide applications for effective management. To assess the impact of temperature on the production of infective conidia, 10-day-old sporulating colonies were exposed to $18,30,33,36,39$, and $42^{\circ} \mathrm{C}$ for $6 \mathrm{~h}$, and then incubated at $18^{\circ} \mathrm{C}$ for $18 \mathrm{~h}$. Conidia were harvested, inoculated onto hop plants, incubated at $18^{\circ} \mathrm{C}$ for 10 days, and then lesions $/ \mathrm{cm}^{2}$ of leaf area was determined. Disease was significantly reduced at temperatures $\geq 30^{\circ} \mathrm{C}$ with a nonlinear response in the production of infective conidia $(P<0.0001)$. Temperature effects on sporulation of $P$. macularis were examined using a custom impaction conidia sampler in growth chambers programmed at constant temperatures of $5,10,15,20,25,30$, and $35^{\circ} \mathrm{C}$, or $18^{\circ} \mathrm{C}$ before and after ramping to $18,22,26,30,34$, and $38^{\circ} \mathrm{C}$ for $6 \mathrm{~h}$. The effect of constant temperature on sporulation was best described by a nonlinear thermodynamic model $(P=0.0001)$ with maximal production near $25^{\circ} \mathrm{C}$. Exposure to fluctuating temperatures produced a curvilinear response in sporulation $(P=0.0122)$ with maximum production near $25^{\circ} \mathrm{C}$. These data indicate that inoculum availability is reduced when ambient temperature exceeds $30^{\circ} \mathrm{C}$ and that modeling inoculum availability could help further refine current disease forecasting models.
\end{abstract}

Hop powdery mildew, caused by Podosphaera macularis, is an economically important disease of hops (Humulus lupulus L.) worldwide, which can result in $100 \%$ crop loss if not controlled. The disease is polycyclic with the potential for more than 20 generations in a growing season (2) if conditions are optimal. Healthy sporulating colonies may produce as many as $3.53 \times 10^{5}$ conidia $/ \mathrm{cm}^{2}$ of colony area (2), which are readily wind disseminated. These traits can result in explosive epidemics where disease incidence on leaves can approach $100 \%$ within 8 weeks after shoot emergence in the spring (8).

Corresponding author: W. F. Mahaffee

E-mail: walt.mahaffee@ars.usda.gov

The use of trade, firm, or corporation names in this publication is for the information and convenience of the reader. Such use does not constitute an official endorsement or approval by the United States Department of Agriculture or the Agricultural Research Service of any product or service to the exclusion of others that may be suitable.

Accepted for publication 25 November 2008.

doi:10.1094/PDIS-93-3-0281

This article is in the public domain and not copyrightable. It may be freely reprinted with customary crediting of the source. The American Phytopathological Society, 2009.
Current management of the disease is accomplished by prophylactic applications of fungicides using a calendar program or HOPS, an infection risk forecaster (13) adapted from the Gubler/Thomas infection risk forecaster for grape powdery mildew, caused by Erysiphe necator (9). HOPS was modified from the secondary component of the Gubler/Thomas infection risk forecaster by adding a rule to address the effect of precipitation, and by modifying the rules for assessing the impact of temperature on disease development. The use of HOPS has resulted in the reduction of fungicide applications used to manage hop powdery mildew but appears to call for shorter application intervals than necessary to manage the disease (W. F. Mahaffee, unpublished). HOPS assumes that conidia are always present during the asexual phase of the epidemic (13), although this assumption likely is incorrect.

The effects of temperature on conidial production and subsequent infectivity of $P$. macularis when conditions are favorable for infection are unknown. Temperature may impact conidial availability of $P$. macularis in a similar manner to other powdery mildew fungi, where conidial production is reduced or inhibited as temperatures rise above $26^{\circ} \mathrm{C}(6,15,19,26,31-$ $34)$. Germination and risk of infection also are reduced when temperatures are $26^{\circ} \mathrm{C}$ and higher during germination for $P$. macularis (14), as well as for other species that cause powdery mildew $(6,7,15$, 19,22,26,31-34). Since temperatures throughout July and August in the U.S. hop production regions fluctuate between inhibitory supra-conducive daytime highs of 30 to $40^{\circ} \mathrm{C}$ and conducive nighttime lows of 15 to $20^{\circ} \mathrm{C}(14)$, it is likely that conditions for sporulation and dissemination of $P$. macularis may not precede conditions conducive to infection. Therefore, HOPS may incorrectly classify periods as high risk for infection when viable conidia are not present, which could potentially result in unnecessary fungicide applications.

Due to the importance of efficient management of hop powdery mildew in hop production and the unexplored role of temperature on sporulation and infectivity of $P$. macularis, the present study was undertaken to examine the effects of temperature on sporulation of $P$. macularis and whether exposure to supra-conducive temperatures prior to spore release impacted infectivity under optimal conditions. The impact of supra-conducive temperature on infective conidia was assessed. The impacts of constant and brief exposure to supra-optimal temperatures on sporulation also were examined.

\section{MATERIALS AND METHODS}

Plant maintenance. Clonal plants of cultivar Symphony (John I. Haas, Inc., Yakima, WA) were propagated from greenwood cuttings (10). Rooted cuttings were transplanted to $5 \times 5 \times 10 \mathrm{~cm}$ pots with a mixture of Sunshine Mix \#1 (SunGro Horticulture, Bellevue, WA) and Soil Moist (JRM Chemical, Cleveland, $\mathrm{OH}$ ) to reduce irrigation frequency. Plants were grown under greenhouse conditions (15 to $26^{\circ} \mathrm{C}$ ) with an approximately $16-\mathrm{h}$ photoperiod and fertigated with Champion 17 17-17 fertilizer with micronutrients (McConkey's, Portland, OR) with each irrigation. Plant material was kept free from powdery mildew infection by vaporizing sulfur in the greenhouse daily (14).

Infectivity experiment. Plants with two to four unfurled leaves and the apical bud removed were inoculated with a suspension of conidia from Oregon field populations of $P$. macularis at $2 \times 10^{4}$ conidia $/ \mathrm{ml}$ in a solution of Tween $20(0.05 \% \mathrm{vol} / \mathrm{vol})$ 
and ultra pure water (Nanopure with organic-free cartridge kit [Barnstead, Dubuque, IA]). The plants were incubated for 10 days at $18^{\circ} \mathrm{C}$ in a growth chamber with a $16-\mathrm{h}$ photoperiod. Then $4.2 \mathrm{~kg} / \mathrm{cm}^{2} \mathrm{com}$ pressed air was applied to the leaves to remove conidia, and the plants were subsequently incubated an additional $24 \mathrm{~h}$ at $18^{\circ} \mathrm{C}$. Plants were then placed at 18,30 , $33,36,39$, or $42^{\circ} \mathrm{C}$ at 1:00 P.M. for $6 \mathrm{~h}$ and returned to $18^{\circ} \mathrm{C}$ for $14 \mathrm{~h}$ to simulate exposure to supra-conducive temperatures during the day and conducive temperatures during the night. Conidia from each plant were harvested by washing leaves in a $0.05 \%$ Tween solution. The final concentration of the conidia suspension was adjusted to $2 \times 10^{4}$ conidia $/ \mathrm{ml}$, applied to disease-free plants, and dried within 30 min of beginning the washing step. The inoculated plants were incubated at $18^{\circ} \mathrm{C}$ for 10 days before enumerating colonies $/ \mathrm{cm}^{2}$ leaf area. The experimental design was a randomized complete block design with replications in time. Growth chambers were randomly assigned a temperature treatment for each replication. There were two experiments, both with three replicates in time with three subsamples per treatment. Linear and nonlinear regression analyses were conducted using Sigma Plot version 10.0 (Systat Software Inc., Chicago, IL).

Sporulation experiments. Inoculation procedure. Young plants with two to four newly unfurled leaves were chosen for inoculations. All leaves on the plants and the apical bud were removed with the ex-

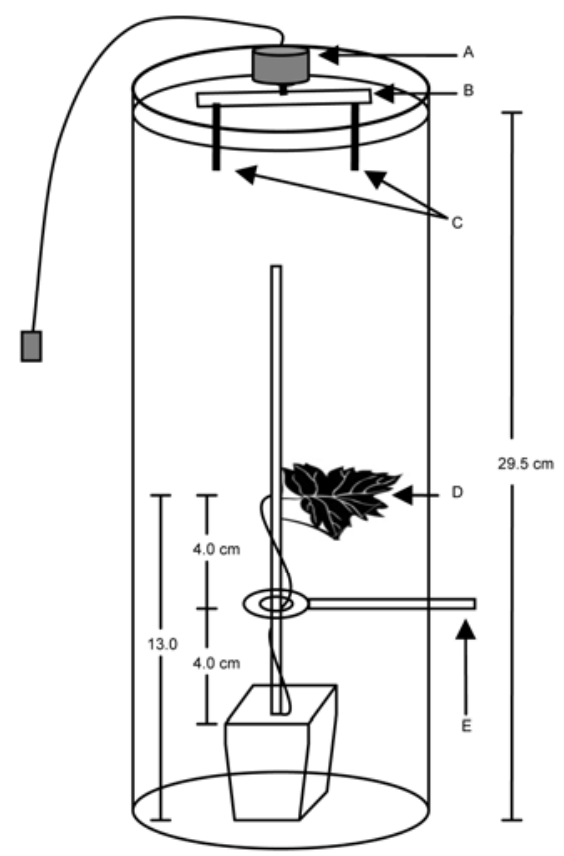

Fig. 1. Prepared plants in plastic vessels mounted with impaction conidia sampler. A, Motor to power rotating sampling arm; B, sampling arm; C, acrylic collector rods; D, diseased leaf; and $\mathrm{E}$, tubing attached to a perforated ring to allow for blasts of air into the vessel. ception of the first two fully unfurled leaves. Plants were inoculated with a conidial suspensions of $6 \times 10^{4}$ conidia/ml as above. Plants were dried in a growth chamber at $25^{\circ} \mathrm{C}$ within an hour of washing the conidia from the leaves of the inoculum source, and then moved to an incubating chamber set at $18^{\circ} \mathrm{C}$ with a $16-\mathrm{h}$ day length $\left(18.7+/-1.7 \mu \mathrm{mol} / \mathrm{s} / \mathrm{m}^{2}\right.$ within a vessel) until mature sporulating colonies had developed (ranging from 9 to 14 days after inoculation).

Once mature sporulating colonies had developed, the plants were removed from the incubation chamber. Plants were pruned to one infected leaf per plant, and compressed air was used to remove conidia from colonies, as above. To minimize variation among plants, selected leaves were of similar size $\left(19.9\right.$ to $\left.27.9 \mathrm{~cm}^{2}\right)$ and phenological age (5 to 7 nodes back from the apical bud). Perforated tubing was placed around the stem of the plant $4 \mathrm{~cm}$ below the infected leaf, and the plants were placed in plastic vessels (Snapware, Inc, Mira Loma, CA) that were $29.5 \mathrm{~cm}$ tall and $11.8 \mathrm{~cm}$ in diameter with an airtight lid. The lids of the plastic vessels were mounted with custom impaction conidia samplers (Fig. 1), which sampled the air at 34.5 liters/min using $1.5 \times 32$ $\mathrm{mm}$ acrylic collector rods (Multidata, Plymouth Meeting, PA) coated with a thin layer of petroleum jelly (Vi-Jon Laboratories, Inc., St. Louis, MO). Tubing was attached to the perforated ring (Fig. 1E), which would later allow for blasts of air into the vessel during air sampling. The collector rods (Fig. 1C) were installed in the sampling arm of the impaction conidia sampler (Fig. 1B), and the lids were closed. Finally, the vessels were placed in the growth chambers; thus, no disturbance of the plants occurred prior to turning on the conidia samplers after the incubation period (described below).

Constant temperature. To assess the effect of constant temperature on sporulation, four plants within four vessels were placed in each of six growth chambers programmed to run at a constant temperature of $5,10,15,20,25,30$, or $35^{\circ} \mathrm{C}$ with a 16-h photoperiod $\left(18.7+/-1.7 \mu \mathrm{mol} / \mathrm{s} / \mathrm{m}^{2}\right.$ within a vessel). One plant was placed in a vessel that was not equipped with an impaction conidia sampler, and was used to visually assess conidia production and morphology following exposure to each temperature. Temperature and humidity were monitored in this vessel with a HOBO U10 Temp/RH Data Logger (Onset Computer Corp., Bourne, MA) suspended on monofilament just below the lid. The remaining three plants were used for conidia collection. Conidia collection occurred following the 48-h incubation.

6- $h$ exposure at different temperatures. To assess the effect of exposure to a range of temperatures for $6 \mathrm{~h}$, four plants in four vessels were placed in 6 different growth chambers programmed to run at $18^{\circ} \mathrm{C}$ for 6 $\mathrm{h}$, then at $18,22,26,30,34$, or $38^{\circ} \mathrm{C}$ for 6 h, and back down to $18^{\circ} \mathrm{C}$ for $12 \mathrm{~h}$ (Fig. 2). The plants were incubated for $24 \mathrm{~h}$ with a 16-h photoperiod $\left(18.7+/-1.7 \mu \mathrm{mol} / \mathrm{s} / \mathrm{m}^{2}\right.$ within a vessel), which began when the vessels were placed in the growth chambers. Conidia collection (described below) occurred following the 24-h incubation.

Conidia collection and enumeration. Conidia were collected by turning on the custom impaction conidia samplers followed by dislodging the conidia with air blasts of $2.81 \mathrm{~kg} / \mathrm{cm}^{2}$ at intervals of 1 blast/s for $15 \mathrm{~s}, 1$ continuous blast for $10 \mathrm{~s}$, and $1 \mathrm{blast} / \mathrm{s}$ for $5 \mathrm{~s}$, for a total of $30 \mathrm{~s}$ of air supplied through the perforated tubing. The conidia samplers were allowed to run

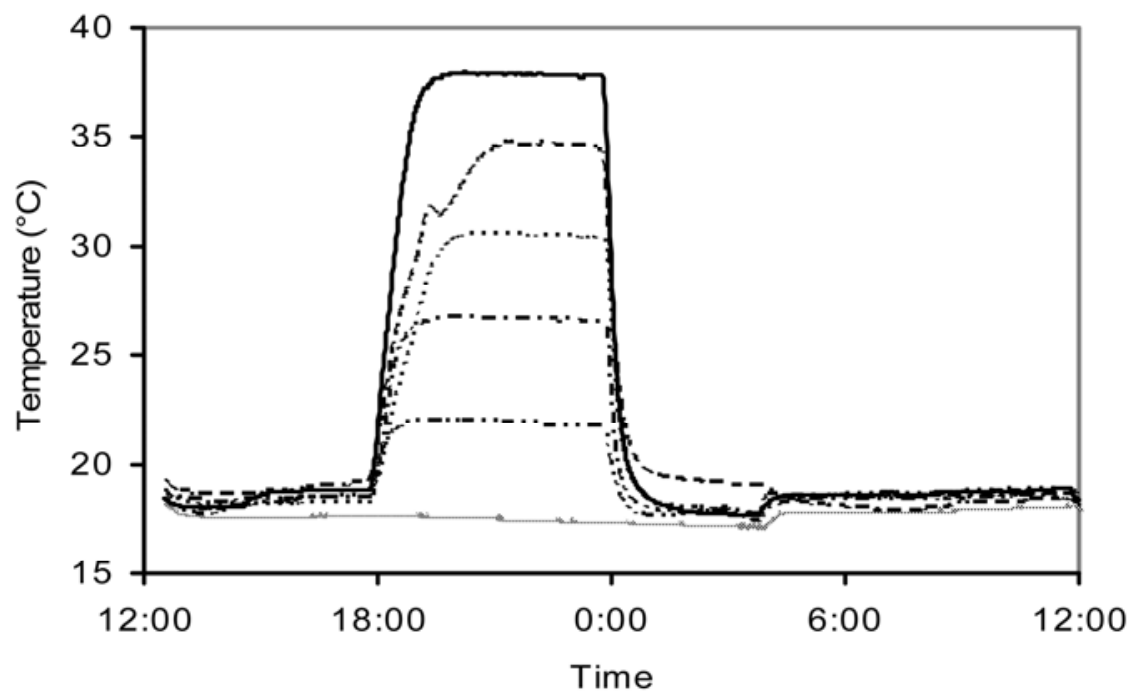

Fig. 2. Temperature recorded within a vessel in each growth chamber used for the 6-h exposure experiment. Each line represents temperature recorded during the 24-h incubation prior to sample collection: 6-h exposure to $38^{\circ} \mathrm{C}$ (solid line); $34^{\circ} \mathrm{C}$ (dashed line); $30^{\circ} \mathrm{C}$ (dash-dot line); $26^{\circ} \mathrm{C}$ (dotted line); $22^{\circ} \mathrm{C}$ (dash-dot-dot line); and $18^{\circ} \mathrm{C}$ (light gray line). 
for $15 \mathrm{~min}$, which sampled $>57 \times$ the air volume of the vessel prior to retrieving the rods. Conidia on the leading edge of both rods were enumerated under a compound microscope at $\times 10$. Colony area was determined using Assess image analysis software (American Phytopathological Society, St. Paul, MN).

Sporulation experiments were randomized complete block designs, with replications occurring in time. Growth chambers were randomly assigned a temperature regime for each replication. The constant temperature experiment had 3 replications with 3 subsamples per replication, and the 6-h temperature exposure experiment had 7 replications with 3 subsamples per replication.

The number of conidia collected on the rods was converted to the number of conidia $/ \mathrm{cm}^{2}$ of colony area for each leaf, and averaged over subsamples and replications. The relationship between temperature treatments and sporulation was described following multiple regression procedures. Quadratic, cubic, and nonlinear effects of constant temperature and 6-h exposure to a range of temperatures were tested. The data were fit to several polynomial, epidemiological, and nonlinear thermodynamic models $(23,25,31)$ using SAS version 9.1 (SAS, Cary, NC). Equations that resulted in regression terms whose coefficients were not significantly different from zero $(P>0.05)$ were dropped from the analysis.

\section{RESULTS}

Infectivity experiment. There was a significant $(P<0.0001)$ nonlinear relationship described by a three-parameter Gompertz model $(y=2.29 * \exp \{-\exp [-(X$ $-33.04) /-5.37]\}$ adjusted $\left.R^{2}=0.87\right)$ of the infectivity of conidia to the temperature at which the conidia were produced (Fig. 3). The Gompertz model was chosen to describe the infectivity data because it appeared to best represent the infection in the data and it maintained the infection at or near zero at temperatures greater than $42^{\circ} \mathrm{C}$. Other bimodal curves were not chosen because we lacked data to determine curve symmetry, and prior research indicated that infection can occur from spores produced at $4^{\circ} \mathrm{C}$ (W. F. Mahaffee, unpublished). Infectivity of conidia was significantly reduced at temperatures $\geq 30^{\circ} \mathrm{C}$. Most of the conidia exposed to temperatures $>33^{\circ} \mathrm{C}$ appeared to have reduced turgidity compared to conidia on plants maintained at lower temperatures (Fig. 4).

Sporulation experiments. Sporulation increased with exposure to increasing temperatures up to $20^{\circ} \mathrm{C}$ and began to decrease with exposure to temperatures $>25^{\circ} \mathrm{C}$ (Fig. 5). There was increased variation in numbers of conidia impinged at 15 and $25^{\circ} \mathrm{C}$ among replications. There was a significant $(P<0.0001)$ nonlinear relationship between temperature and the density of conidia produced per $\mathrm{cm}^{2}$ of colony area, which was described by Ratkowsky's (20) four-parameter equation $R(T)=[0.923(T-$ 5.14) $\left.\left(1-e^{0.199(T-34.5)}\right)\right]^{2}$, where $T=$ temperature (adjusted $R^{2}=0.81 ; P=0.0001$ ). The Ratkowsky model was chosen because it appeared to best represent the observed asymmetry in data while resulting in near zero sporulation at the temperature extremes. Other nonlinear models were not chosen because they either did not accurately reflect the changes in the rate of sporulation throughout the response curve, or they did not accurately predict the rate of sporulation at $25^{\circ} \mathrm{C}$.

Visual examination of control plants with colonies exposed to $5,10,15,20$, and $25^{\circ} \mathrm{C}$ revealed that apparently healthy sporulating colonies were present after exposure to the temperature treatments, with mature conidia available for collection among these treatments. Conidia from colonies exposed to $30^{\circ} \mathrm{C}$ appeared desiccated and had fewer mature conidia present than plants exposed to lower temperatures. Colonies exposed to $35^{\circ} \mathrm{C}$ appeared desiccated with few mature conidia present (Fig. 4).

Effect of 6-h exposure at different temperatures. There was a significant quadratic relationship $\left(y=-1.11 x^{2}+\right.$ $59.39 x-636.10$, where $x=$ temperature; adjusted $R^{2}=0.91 ; P=0.0122$ ) between temperature and number of conidia/ colony area (Fig. 6). A simple quadratic equation was chosen to describe the sporulation data compiled from the 6-h temperature exposure experiments because it was the most parsimonious model and had the greatest significant fit to the data when compared with other polynomial, epidemiological, and nonlinear thermodynamic models.
The mean number of conidia sampled increased with temperature up to $26^{\circ} \mathrm{C}$, and then decreased thereafter. There was increased variation in numbers of conidia impinged at $26^{\circ} \mathrm{C}$ (Fig. 6).

Visual assessment of control plants indicated desiccation of conidia occurring on control plants exposed to $34^{\circ} \mathrm{C}$. This effect was more pronounced on control plants exposed to $38^{\circ} \mathrm{C}$. Colonies on control plants exposed to $34^{\circ} \mathrm{C}$ and above appeared to have fewer mature conidia than colonies on control plants exposed to 22 , 26 , and $30^{\circ} \mathrm{C}$.

\section{DISCUSSION}

The effect of temperature on sporulation presented here indicates that inoculum is not always readily available after periods of exposure to temperatures greater than $30^{\circ} \mathrm{C}$. Also, infectivity of conidia was reduced when the conidia were produced during exposure to temperatures of $30^{\circ} \mathrm{C}$ and higher. These data indicate that an accurate assessment of the potential for disease development should account for how temperature impacts inoculum availability.

Previous research has shown that infection severity and lesion expansion of $P$. macularis were reduced by exposure to supra-optimal temperatures $(14,27)$. Our results indicate that while conidia are produced at supra-optimal temperatures, their infectivity is significantly reduced. The findings of past research and the present study indicate that the fecundity of $P$. macularis is decreased as temperatures deviate from the optimal range of 18 to $25^{\circ} \mathrm{C}$. These results also offer an explanation of why epidemics in U.S. hop yards slow during July and August when tem-

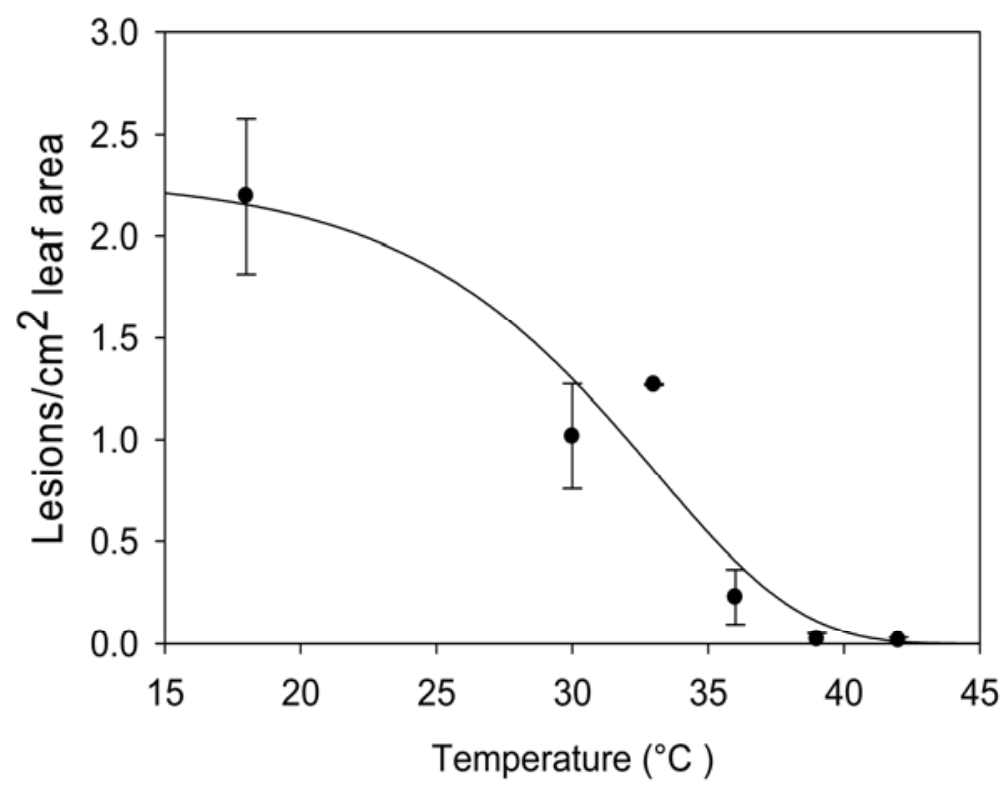

Fig. 3. Effect of temperature on infectivity of conidia of Podosphaera macularis on hop. Each point is the mean of two experiments each with three replications and three subsamples per replication \pm standard deviation from the mean. The line was generated by a 3-parameter Gompertz model where $y=$ $2.29 * \exp \{-\exp [-(X-33.04) /-5.37]\}$, where $X=$ temperature (adjusted $\left.R^{2}=0.87 ; P<0.0001\right)$. 
peratures routinely exceed $30^{\circ} \mathrm{C}$ for more than $6 \mathrm{~h}$ (27). The results indicate that the greatest potential of disease development is during periods when daily temperature highs and lows are within 5 to $10^{\circ} \mathrm{C}$ of the optimal temperature for sporulation. As such, HOPS could be refined by account- ing for the effects of temperature on inoculum availability.

Our results indicate that infectivity of $P$. macularis conidia is significantly reduced at temperatures greater than or equal to $30^{\circ} \mathrm{C}$. In comparison, E. graminis is slightly more sensitive to temperatures, as
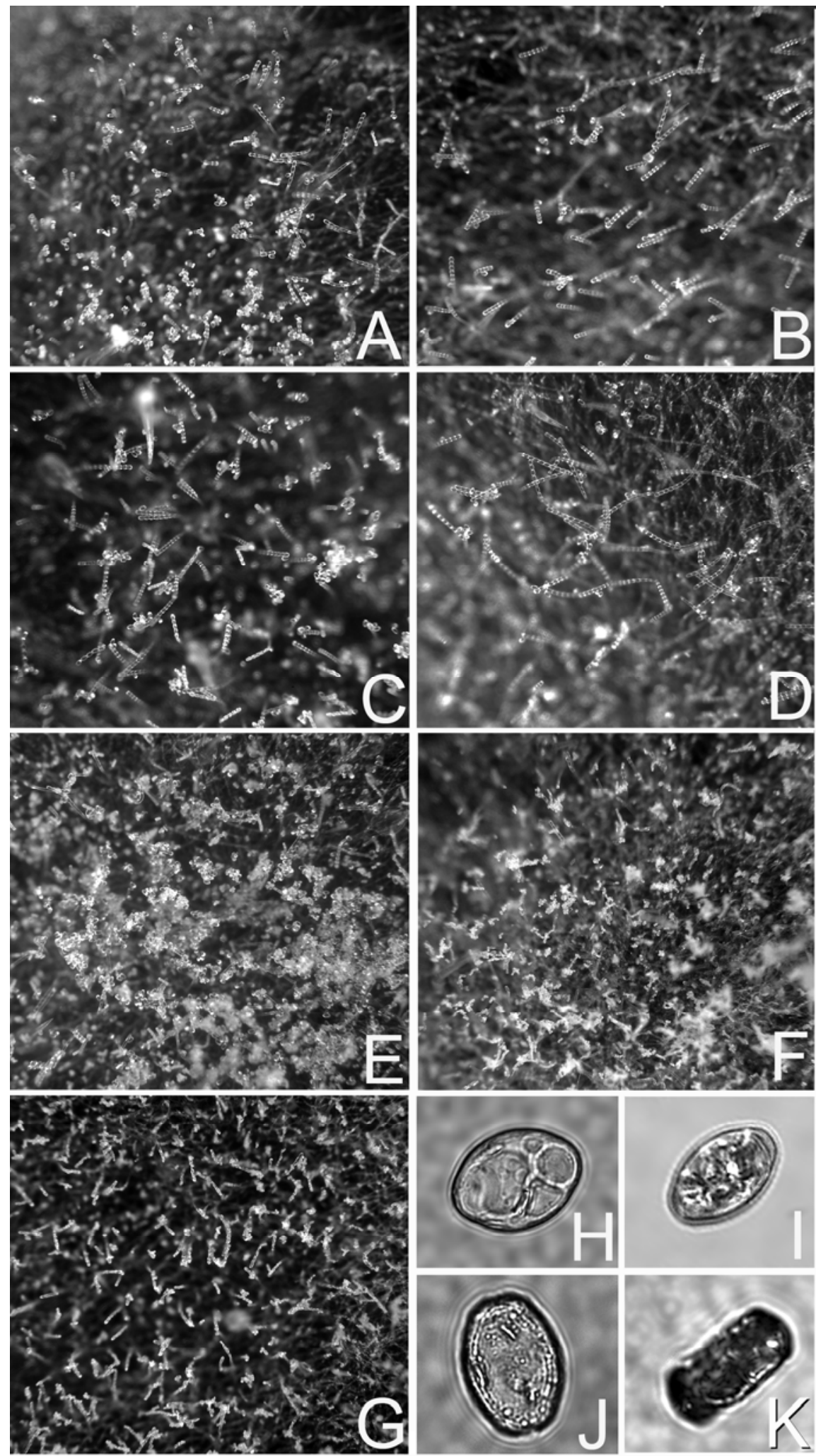

Fig. 4. Conidia of Podosphaera macularis produced at a range of temperatures for $48 \mathrm{~h} . \mathbf{A}, 5^{\circ} \mathrm{C} ; \mathbf{B}$, $10^{\circ} \mathrm{C} ; \mathbf{C}, 15^{\circ} \mathrm{C} ; \mathbf{D}, 20^{\circ} \mathrm{C} ; \mathbf{E}, 25^{\circ} \mathrm{C} ; \mathbf{F}, 30^{\circ} \mathrm{C} ; \mathbf{G}, 35^{\circ} \mathrm{C} ; \mathbf{H}$ to $\mathbf{K}$, typical appearance of conidia exposed to $5-20^{\circ} \mathrm{C}(\mathbf{H}), 25^{\circ} \mathrm{C}(\mathbf{I}), 30^{\circ} \mathrm{C}(\mathbf{J}), 35^{\circ} \mathrm{C}(\mathbf{K})$.

the infectivity of conidia produced at temperatures above $20^{\circ} \mathrm{C}$ and $7^{\circ} \mathrm{C}$ are significantly reduced $(12,29)$. Visual analysis of conidia produced at $30^{\circ} \mathrm{C}$ and above indicated that many were desiccated (Fig. 4). Quinn and Powell (19) observed that there was a direct relationship between percent turgid conidia and percent conidia germination, indicating that desiccated conidia are not viable. This conclusion is further supported by the infectivity experiments, where less disease developed from conidia produced at $30^{\circ} \mathrm{C}$ and above compared to those produced at $18^{\circ} \mathrm{C}$. Quinn and Powell (19) also found that after exposure to supra-optimal temperatures, hyphal growth stopped and haustoria became shriveled. Other research has also shown that exposure of conidia to supra-optimal temperatures results in a decrease in rates of germination and infectivity $(7,14,16,27,29)$.

The reductions in sporulation and infectivity are likely due to a combination of factors, which are difficult to disentangle due to the close interaction between the pathogen and the host. Changes in plant physiology may lead to a decrease in the processes involved in conidia production in a number of ways. Direct sunlight can cause the surface of a leaf to be 3 to $7^{\circ} \mathrm{C}$ hotter than ambient temperature due to transference of radiant energy (3). This increase in temperature could cause the conditions at the leaf surface to be above the upper temperature threshold conducive for fungal development. High temperatures lead to the host closing its stomata to conserve water (11), thereby lowering the relative humidity within the boundary layer. In turn, this could remove a buffer from extreme temperatures. Extreme temperatures and low relative humidity are parameters that can be unfavorable conditions for germination, infection, or sporulation of powdery mildews $(2,7,14,34)$, since their entire life cycle is almost wholly external to the host, and only haustoria are present within host tissues. Changes in fungal metabolism in response to temperature also may cause a reduction in conidial production, as fungi do not regulate their internal temperature and greater temperatures increase the likelihood of cellular damage (28). Alternatively, it has been speculated that when a pathogen develops at supra-optimal temperatures, it may enhance the resistance of the host response (26).

Despite extensive measures to reduce variability in the sporulation studies (i.e. selecting similar aged leaves, plants, colonies, colony density, controlled environmental conditions, leaf position, and height from air source, etc.), there was still a large amount of unexplained variation in the number of conidia/colony area among replications of the sporulation studies. This is a common occurrence in sporulation studies $(4,5,29-31,35)$. This variability is likely due to differences in colony density, 
location, or differences in plant physiology.

The variability in sporulation may have been a result of differences in the greenhouse environment over the course of propagating and growing the plants used in experiments since replications were conducted in time. Mahaffee et. al. (14) demonstrated that exposure to supra-conducive temperatures shortened the time in which leaves were susceptible to infection, and it is likely that factors influencing susceptibility also impact the ability of existing colonies to obtain nutrients and water, thereby impacting rate of conidia development. Similarly, differences in susceptibility have been linked to water stress (17). There may be similar effects on differing levels of oncogenic (age related) resistance among the plants used caused by subtle differences in plant fertility (11), water stress, or exposure to greenhouse temperatures.

Studies on other powdery mildew fungi indicate that colony density may influence sporulation potential $(18,21)$. When recording leaf and colony areas for the sporulation experiments, it was observed that some leaves had colonies on the abaxial surfaces that were not visible or were missed when selecting plants for experiments. The location of colonies may have influenced the efficacy with which the applied air blasts caused conidia to be dislodged from conidiophores, or perhaps differences in colony density may have

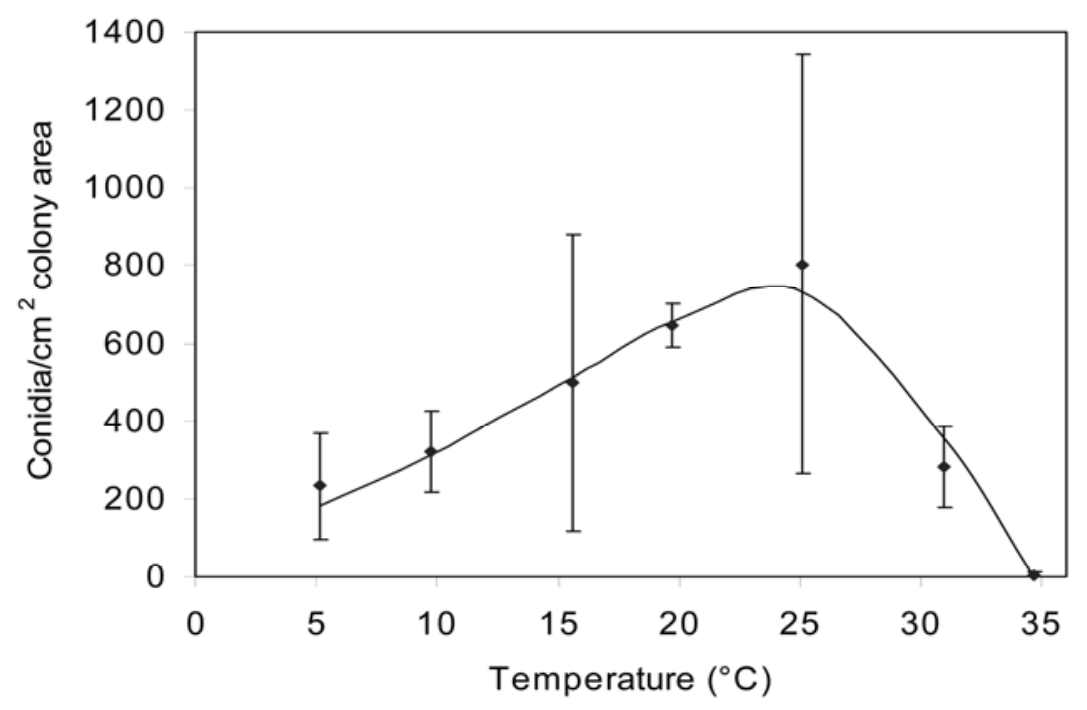

Fig. 5. Effect of constant temperature on sporulation of Podosphaera macularis on hop. Each point is the mean of three replications with three subsamples per replication \pm standard deviation from the mean. The line was generated by the Ratkowsky model $R(T)=\left[0.922(T-5.14)\left(1-e^{0.199(T-34.5)}\right)\right]^{2}$, where $T=$ temperature (pseudo- $R^{2}=0.81 ; P=0.0001$ ).

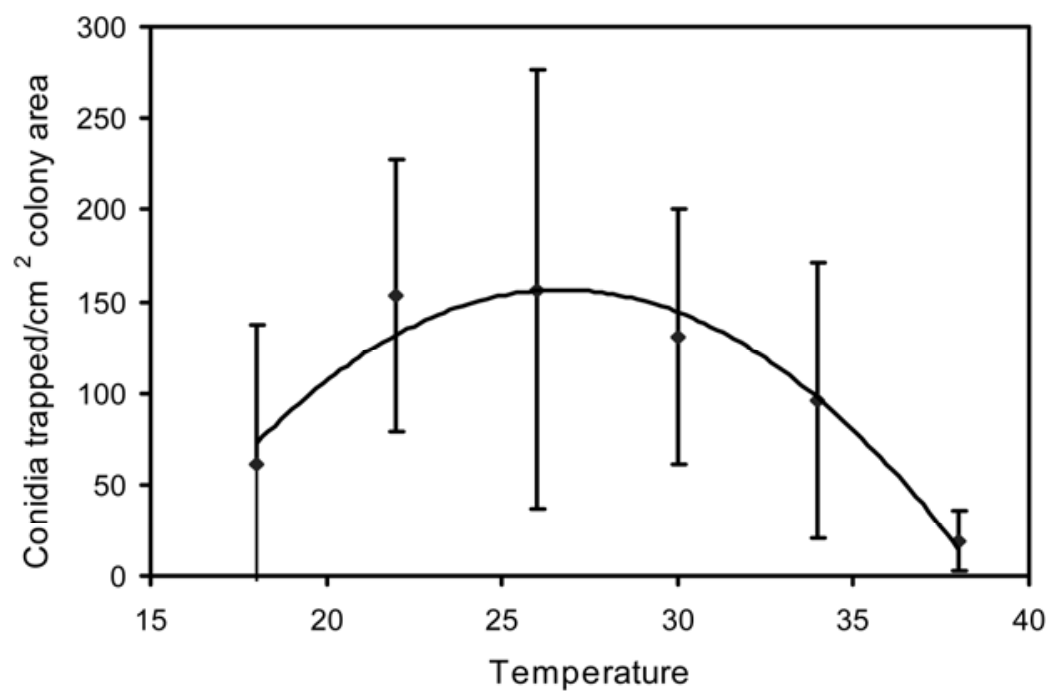

Fig. 6. Effect of exposure to different temperatures for $6 \mathrm{~h}$ on sporulation of Podosphaera macularis on hop. Each point is the mean of three replications with three subsamples per replication \pm standard deviation from the mean. The line is the quadratic polynomial model described by $y=-1.11 x^{2}+$ $59.39 x-636.10$, where $x=$ temperature (adjusted $R^{2}=0.91 ; P<0.0001$ ).

influenced the sporulation potential of these colonies $(18,21,25)$.

The data presented here indicate that the assumption of continuous and uniform inoculum availability by the HOPS infection risk forecaster is incorrect at temperatures above $30^{\circ} \mathrm{C}$, where infectivity and sporulation were significantly reduced. These findings indicate that disease or risk forecasters for hop and potentially other powdery mildews may be improved by accounting for the effect of temperature on inoculum availability. Accounting for inoculum availability likely will increase the accuracy of infection risk estimates and enhance the economic and environmental sustainability of hop production. Visual observations of conidial desiccation indicate that further research is needed on the effects of temperature on inoculum viability and infection potential in order to better account for the effect of temperature on disease epidemics.

\section{ACKNOWLEDGMENTS}

We thank Andrew Albrect, Madeline Dildine, Clare Elliot, and Tara Neill for technical assistance and Nik Grünwald for assistance with SAS programming. Financial support was provided by USDA-ARS CRIS 303-5358-22000-030-00D and 5358-21000-035-00 and grants from the Hop Research Council.

\section{LITERATURE CITED}

1. Bainbridge, A., and Legg, B. J. 1976. Release of barley-mildew conidia from shaken leaves. Trans. Br. Mycol. Soc. 66:495-498.

2. Blodgett, F. M. 1913. Hop Mildew. New York Agric. Exp. Stn. Bull. 328:278-328.

3. Burrage, S. 1971. The micro-climate at the leaf surface. Pages 91-101 in: Ecology of Leaf Surface Micro-Organisms. T. Preece and C. Dickinson, eds. Academic Press, London.

4. Chellemi, D. O., and Marois, J. J. 1988. Environmental effects on conidial production by Uncinula nector. Phytopathology 78:1573.

5. Chellemi, D. O., and Marois, J. J. 1991. Effect of fungicides and water on sporulation of $U n$ cinula necator. Plant Dis. 75:455-457.

6. Chellemi, D. O., and Marois, J. J. 1991. Sporulation of Uncinula necator on grape leaves as influenced by temperature and cultivar. Phytopathology 81:197-201.

7. Delp, C. J. 1954. Effect of temperature and humidity on the grape powdery mildew fungus. Phytopathology 44:615-626.

8. Gent, D. H., Turechek, W. W., and Mahaffee, W. F. 2007. Sequential sampling for estimation and classification of the incidence of hop powdery mildew I: Leaf sampling. Plant Dis. 91:1002-1012.

9. Gubler, W. D., Rademacher, M. R., Vasquez, S. J., and Thomas, C. S. 1999. Control of powdery mildew using the UC Davis powdery mildew risk index. Online. APSnet Feature Story, January 1999. American Phytopathological Society, St. Paul, MN.

10. Haunold, A., and Zimmermann, C. E. 1974. Pollen collection, crossing, and seed germination of hop. Crop Sci. 14:774-776.

11. Hopkins, W. G. 1995. Introduction to Plant Physiology. John Wiley \& Sons, New York.

12. Last, F. 1953. Some effects of temperature and nitrogen supply on wheat powdery mildew. Ann. Appl. Biol. 40:312-322.

13. Mahaffee, W. F., Thomas, C. S., Turechek, W. W., Ocamb, C. M., Nelson, M., Fox, A., and Gubler, W. D. 2003. Responding to an Introduced Pathogen: Podsphaera macularis (Hop 
powdery mildew) in the Pacific Northwest. Online. Plant Health Progress doi:10.1094/ PHP-2003-1113-07-RV.

14. Mahaffee, W. F., Turechek, W. W., and Ocamb, C. M. 2003. Effect of variable temperature on infection severity of Podosphaera macularis on hops. Phytopathology 93:1587-1592.

15. Manners, J. 1971. Spore formation by certain pathogens in infected leaves. Pages 339-351 in: Ecology of Leaf Surface Micro-Organisms. T. F. Preece and C. H. Dickinson, eds. Academic Press, London.

16. Miller, T. C., Gubler, W. D., Geng, S., and Rizzo, D. M. 2003. Effects of temperature and water vapor pressure on conidial germination and lesion expansion of Sphaerotheca macularis f. sp. fragariae. Plant Dis. 87:484-492.

17. Neve, R. A. 1963. Plant breeding section; review of the year's work. Wye College Dep. Hop Res. Ann. Rep. 1962:7-9.

18. Pady, S. M., Kramer, C. L., and Clary, R. 1969. Sporulation in some species of Erysiphe. Phytopathology 59:844-848.

19. Quinn, J. A., and Powell, C. C., Jr. 1982. Effects of temperature, light, and relative humidity on powdery mildew of Begonia. Phytopathology 72:480-484.

20. Ratkowsky, D., Lowry, R., McMeekin, T., Stokes, A., and Chandler, R. 1983. Model for bacterial growth rate throughout the entire biokinetic temperature range. J. Bacteriol.
154:1222-1226.

21. Rouse, D., MacKenzie, D., and Nelson, R. 1984. Density dependent sporulation of Erysiphe graminis f. sp. tritici. Phytopathology 74:1176-1180.

22. Sall, M. A. 1980. Epidemiology of grape powdery mildew: A model. Phytopathology 70:338-342.

23. Scherm, H., and van Bruggen, A. H. C. 1994. Effects of fluctuating temperatures on the latent period of lettuce downy mildew (Bremia lactucae). Phytopathology 84:853-859.

24. Shaner, G. 1973. Estimation of conidia production by individual pustules of Erysiphe graminis f. sp. tritici. Phytopathology 63:847850.

25. Smits, N., Briere, J.-F., and Fargues, J. 2003. Comparison of non-linear temperaturedependent development rate models applied to in vitro growth of entomopathogenic fungi. Mycol. Res. 107:1476-1484.

26. Stavely, J., and Hanson, E. 1966. Some effects of temperature and relative humidity on development of Erysiphe polygoni on Trifolium pratense. Phytopathology 56:940-943.

27. Turechek, W. W., Mahaffee, W. F., and Ocamb, C. M. 2001. Development of management strategies for hop powdery mildew in the $\mathrm{Pa}$ cific Northwest. Online. Plant Health Progress doi:10.1094/PHP-2001-0313-01-RS.

28. Walker, G. M., and White, N. A. 2005. Intro- duction to fungal physiology. Pages 1-34 in: Fungi: Biology and Applications. K. Kavanagh, ed. John Wiley \& Sons, Indianapolis, IN.

29. Ward, S. V., and Manners, J. G. 1974. Environmental effects on the quantity and viability of conidia produced by Erysiphe graminis. Trans. Br. Mycol. Soc. 62:119-128.

30. Willocquet, L., and Clerjeau, M. 1998. An analysis of the effects of environmental factors on conidial dispersal of Uncinula necator (grape powdery mildew) in vineyards. Plant Pathol. 47:227-233.

31. Xu, X. M. 1999. Effects of temperature on the latent period of the rose powdery mildew pathogen, Spaerotheca pannosa. Plant Pathol. 48:662-667.

32. Xu, X.-M., and Robinson, J. D. 2000. Effects of temperature on the incubation and latent periods of hawthorn powdery mildew (Podosphaera clandestina). Plant Pathol. 49:791-797.

33. Xu, X. M., and Robinson, J. D. 2001. The effects of temperature on the incubation and latent periods of powdery mildew (Erysiphe polygoni) on clematis. J. Phytopathol 149:565-568.

34. Ypema, H. L., and Gubler, W. D. 1997. Longterm effect of temperature and triadimefon on proliferation of Uncinula necator: Implications for fungicide resistance and disease risk assessment. Plant Dis. 81:1187-1192. 